\title{
Real estate crisis and sustainability in Spain
}

\author{
J. L. Miralles i Garcia \\ Department of Urban and Regional Planning, \\ Polytechnic University of Valencia, Spain
}

\begin{abstract}
The last real estate cycle in Spain is a paradigmatic example of non sustainable development. The extraordinary urban development in the 1997-2007 period produced an extraordinary economic growth based on land speculation and housing. The end of the cycle generates a very severe economic crisis, one that is the most serious economic crisis in a long time. This process has economic, social and environmental repercussions; from the economic point of view Spain has a temporally increased its GDP. The real estate activity has generated houses, and land able to be developed, but without use and without a market. From the social point of view, the Spanish people have changed their system of moral value. It takes as an ideal rapid enrichment without effort and without producing useful goods and services, and from the environmental point of view, on building over an extensive area without use. It is an irreversible process of rural land transformation. All land conversion is carried out by urban planning; the landscape changes and "urban sprawl" increases.
\end{abstract}

Keywords: urban planning, landscape architecture, landscape ecology, landscape management, sustainability, public participation.

\section{Introduction}

Spain has seen a process of economic development that is clearly unsustainable. The process occurred mainly between 1997-2007 and a large number of houses were built in this period. In Figure 1 you can see the number of visas given for construction for housing, and in Figure 2 you can see the number of houses built for each year. In 2002-2007 there were more visa granted for construction in Spain than in France and Germany combined. The process is especially intensive in the case of coastal and tourist areas as in the Autonomous Community of Valencia [1]. 
124 Sustainable Development and Planning V

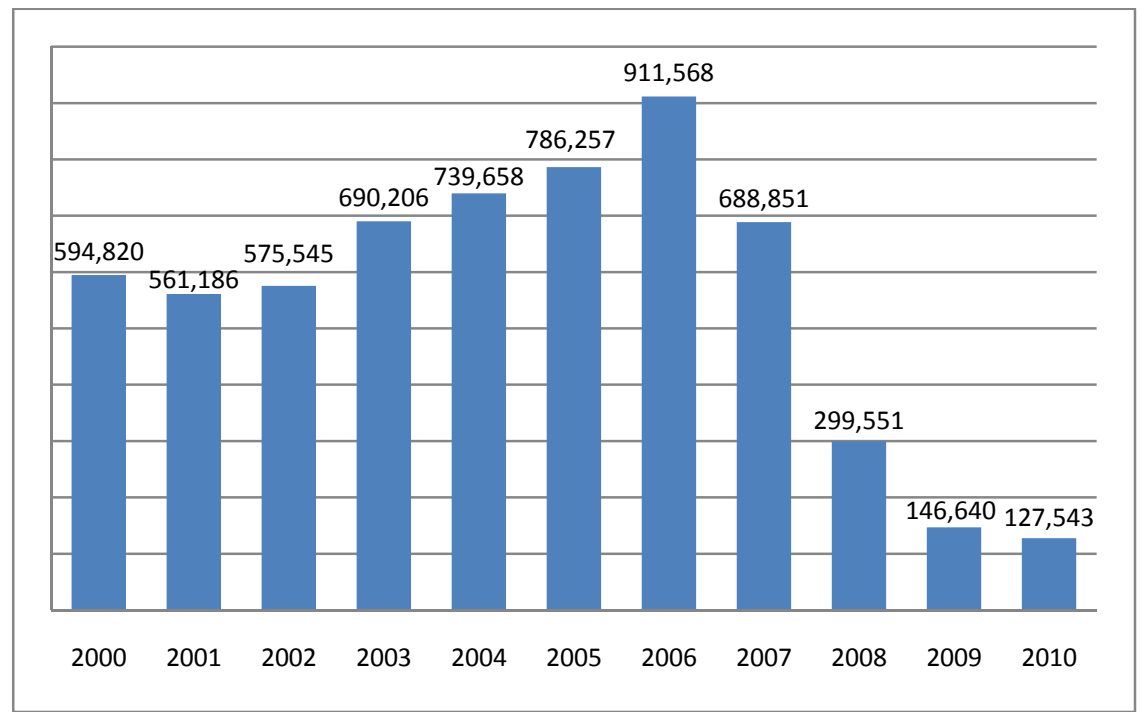

Origin: Ministerio de Fomento (Spain).

Figure 1: Visas for construction work: housing number.

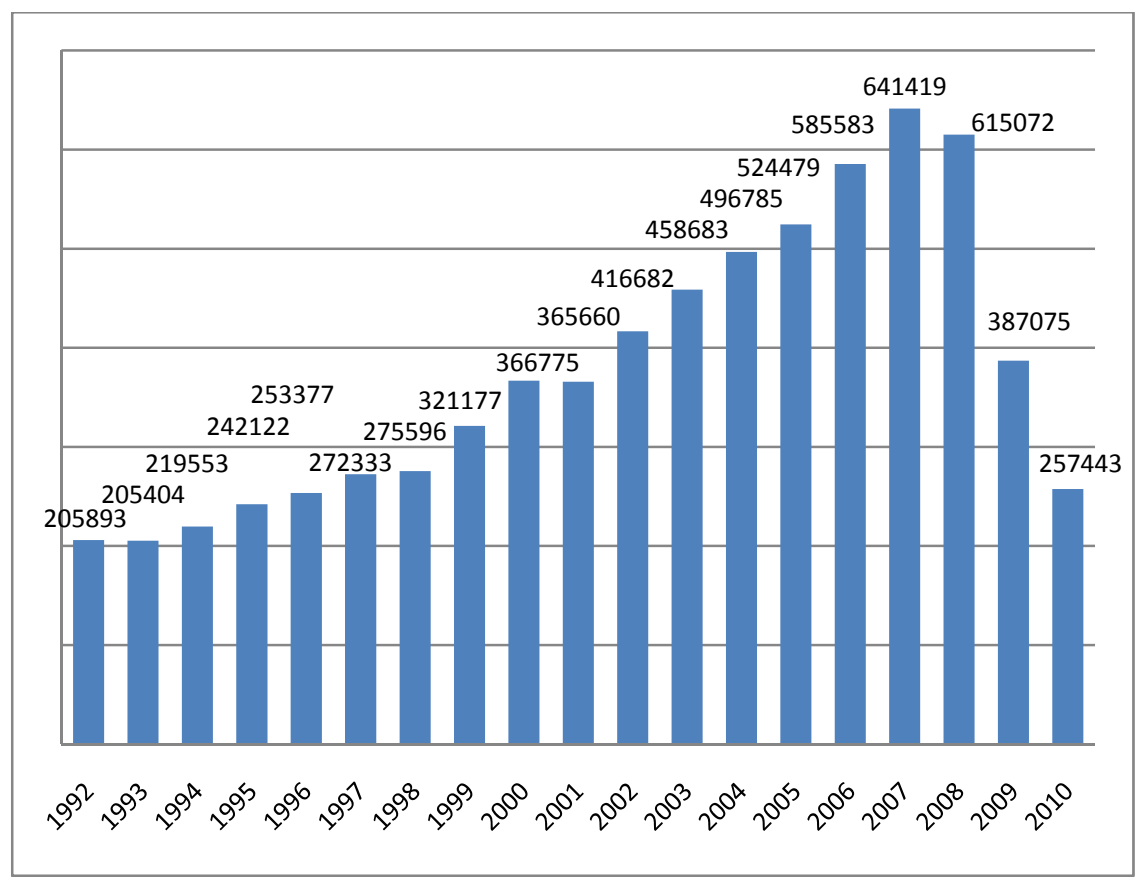

Origin: Instituto Nacional Estadística (Spain).

Figure 2: $\quad$ Number of housing builds for each year. 
The mortgage loans without guarantees of return and the speculative value of land fed the process. In this situation the market demand is fixed by speculative processes.

For saving banks, in February 2011, the Banco de España has determined a figure of $€ 217$ billion as the financial sector's exposure to real estate development and construction as potentially problematic, comprising the following [2]:

- Standard loans under surveillance,

$€ 28$ billion.

- Doubtful loans,

- Foreclosures, $€ 28$ billion. $€ 44$ billion.

As a reference, the GDP of Spain is about $€ 1.000$ billion. In Spain the expansive cycle began about 1997. The financial global problems began around 2007 and that marks the end of the expansive cycle.

The effect of the problems was to generate a moment of shock. The people had accepted urban expansion and speculative processes as a normal situation and so the new situation created surprise.

In coastal and tourist areas, as in the Autonomous Community of Valencia [3], the process is very intensive because an important kind of economic activity is based on construction. They are a paradigmatic example of unsustainable development. By definition, unsustainable development has an end date, while sustainable development is maintained over time.

Spain has seen two expansive real estate cycles and the corresponding crash. In 1960-1972 Spain had their first economic expansive cycle and the first speculative real estate cycle. This cycle is associated to monetary input of foreign investment and tourism. So the more important urban expansion occurred on the coasts, and the processes of land speculation focused on the coast, for example in Valencia. The regressive economic phase lasted from 1972 to 1985. The second growth cycle occurs in the period 1985-1991. In this case the monetary input was caused by the entry of Spain into the EU, European Economic Community at that time. This cycle has been studied in detail for Naredo [4].

The crash of the cycle occurred in 1991 and the regressive phase was very short. It was overcome by the devaluation of the currency (the "peseta" at that time). The regressive period lasted until approximately 1997. None of these cycles were as severe as today.

The model of access to housing for these processes is based on private ownership of land and home ownership. There was never a social housing policy based on public land and housing for rent.

These two real estate cycles generated a certain experience of these processes for the agents involved: local authorities, developers, owners and people in general. Probably people assumed that these cycles were normal and therefore, if there was another cycle, had to take advantage of the speculative growth cycle for personal enrichment. The conditions for a new growth cycle begin to occur about 1997. 


\section{Phases of unsustainable development process}

If we follow the process 6 phases can be identified which you can see in Figure 4. These six phases characterize the process of unsustainable development.

The phases were identified by direct observation of the process in Spain and, particularly in the Autonomous Community of Valencia. The phases fit the evolution of major socio-economic indicators that characterize the real estate cycle or, in general, any development process based on consumption of stocks or reserves.

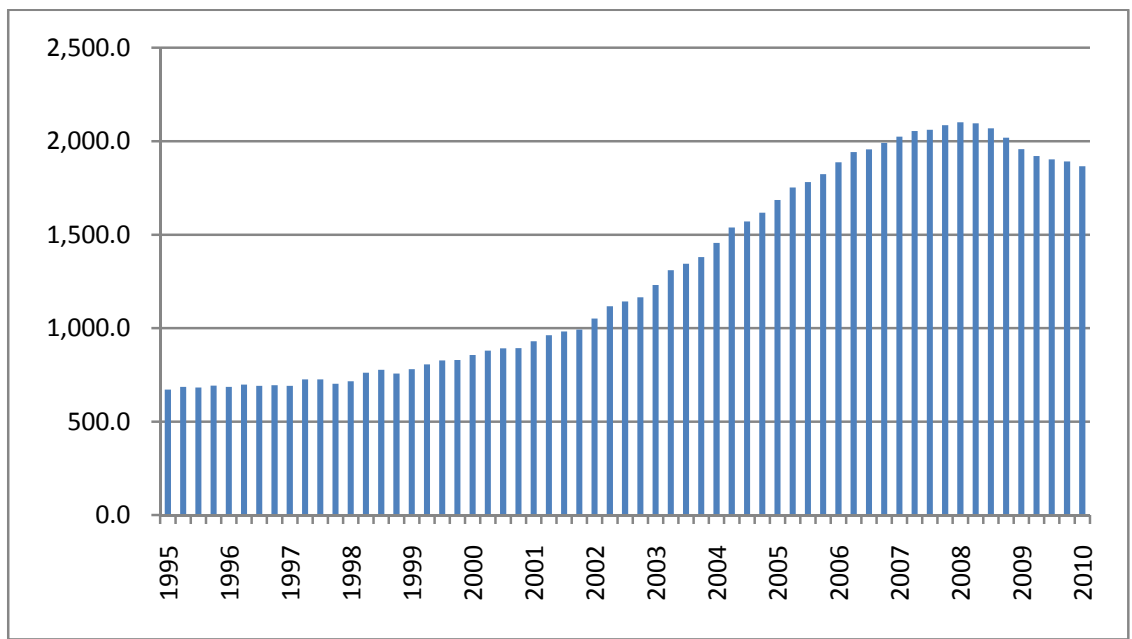

Origin: Ministerio de Fomento (Spain).

Figure 3: $\quad$ Free price houses evolution $\left(€ / \mathrm{m}^{2}\right)$.

\subsection{Initial phase}

The cycle begins when stakeholders identify the possibility to consume stock. In our case the bank began a practice of lending mortgages. These mortgage loans had as a guarantee a very high percentage of the value of the home. In fact the bank began to lend above the long-term recovery.

By mortgages funds (generation of financial products sold to other banks in the international market), banks could continue the lending process. In Valencia and Spain, the bank began a process of unsecured loans of return flow generating an artificial money supply. Really a process of stored capital spending because a return was doubtful.

This situation will always occur if there is a consumption of resources, for example oil [5]. Oil is a non-renewable natural capital. Any consumption means reduced stock. Therefore, necessarily, any economic development based on its consumption is not sustainable. This situation can be corrected if one takes the precaution of estimating future and current sacrifices being made to ensure the 


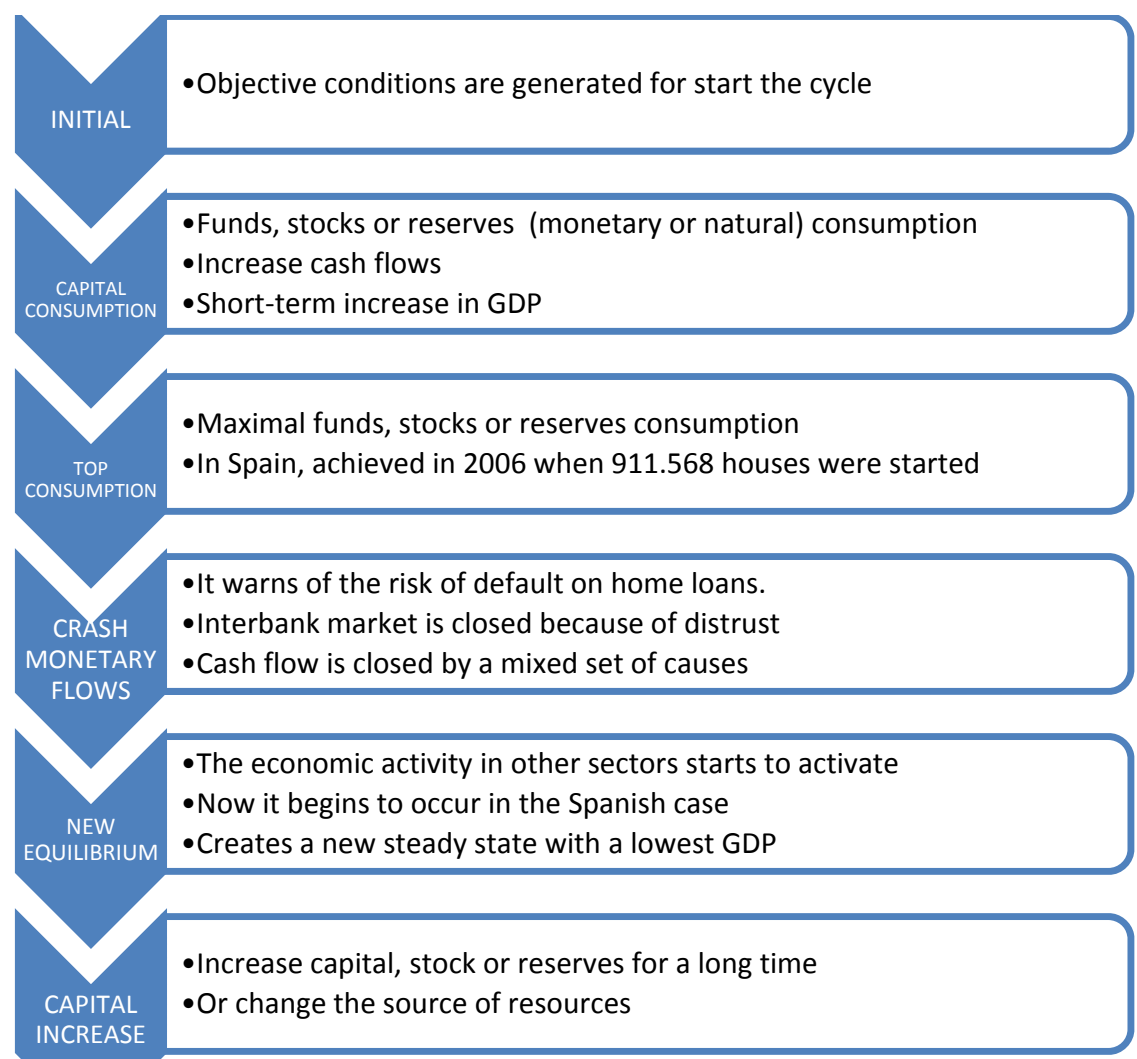

Figure 4: The phases of unsustainable development.

balance of consumption in the future (improve efficiency, find other resources, to change urban activity ... in general applying the most efficiency and/or new technology).

The initial phase was produced in Spain between 1994 and 1999. The unemployment rate in Spain was $15 \%$. The average house price was stable at $700-800 € / \mathrm{m}^{2}$. The number of building visas for new housing was 300.000 350.000 houses / year. They are data for a relative balance.

In this time, forms of private management of urban development were generated that streamlined the administrative process. For example the urban development agent was regulated in Valencian law [6].

\subsection{Capital consumption phase}

After first phase we have a process of capital (stocks or reserves) consumption. At this stage we have a process of economic growth with high annual increases in GDP, which is mainly based on the consumption of a stock. In our case, to consume the capital stock of money through loans to houses buyers and urban 
developers. The cash flow produced generates a Ponzi scheme with feedback. That is, the loans awarded push up the prices of housing and land. The price increase encourages investors and banks to make more loans which in turn push up prices further. During this period in Spain, house prices rose about 15\% annually while GDP or wages rose about $3-4 \%$ annually.

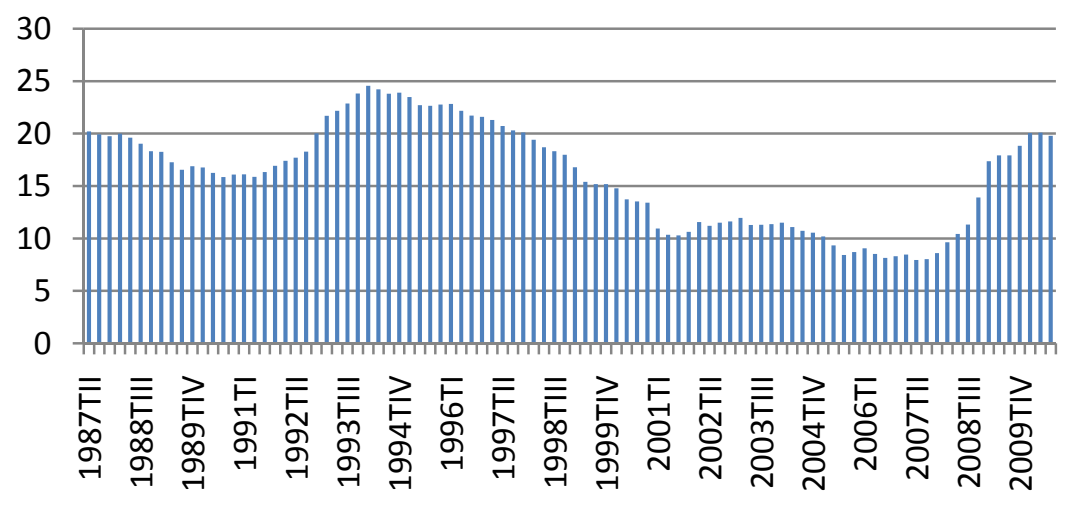

Origin: Instituto Nacional de Estadística (Spain).

Figure 5: Quarterly unemployment rate in 1987-2009 (Spain).

In this period, for urban developers, many loans were obtained by evaluating the land expectation value for future urban development. That is why many loans are risky assets.

The increased cash flow generated a spectacular production of housing and a spectacular increase in land prices and housing (see Figures 1, 2 and 3).

All stakeholders approve the process:

- The landowners note that effortlessly the land price go up from a lower agricultural value of $1 \mathrm{euro} / \mathrm{m}^{2}$ to $180 \mathrm{euro} / \mathrm{m}^{2}$ as maximum value for developable land. Most landowners are small local owners integrated to a large part of local society.

- The urban developers can benefit from up to $30-40 \%$ if they get to buy land cheap and sell the same land expensively for housing.

- The builders and the construction sector find a very big source for work.

- The local government gets the land free transfer of public facilities (roads, green areas and facilities and, usually, $10 \%$ of urban profit as building land). The urban development becomes a source of revenue for local government.

- Houses buyers, for residence or investment, are also in favour because they have easy credit.

So the greater part of people and democratically elected governments (with short-term interests) are approving of the process.

But the process has generated a major transformation of rural land to urban land. This transformation is irreversible; sometimes natural heritage has not been preserved. Any transformation is by urban planning but sometime environmental 
documents for urban planning have been used to justify decisions already taken by agents involved. Against major economic interests, environmental issues are minimized or not considered.

Some NGOs were created to oppose the urban development of certain areas and defend public environmental interests. In Valencia, the most representative case is the movement (with the name Per L'Horta) for preservation of the irrigated region around Valencia. This movement promoted in 2001 a legislative initiative for protection which obtained 118,000 signatures of support. The proposal was rejected by the Valencian Parliament. The two major political parties expressed their opposition to the initiative. After the Valencian government promoted a Special Plan for Protection, but it has not yet been approved [7].

This period lasted about 8 years between 1999 and 2007 and has produced a set of social and economic changes:

- The capital is being spent. At this time debt has been increasing and capital decreasing, but this process is imperceptible.

- In parallel people have been strong consumers of goods and services easily accessible. Thus people have been in a situation of abundance and they think it will always be. People lose the value of work and think that isn't necessary to work to obtain goods and services.

- There was a building asset (land and housing) with speculative value. The people have a sense of wealth. It is thought that the possession of this heritage guarantees wealth.

- People who got rich in a few years by land speculation became socially ideal. It changes the value system and the success is associated with rapid enrichment.

- The productive activities with low relative profitability i.e. $5-10 \%$ decrease because real estate development is much more lucrative.

- The process in this phase generates continued increases in housing prices, about $10-18 \%$ annually. The bank makes loans even above the value of the mortgaged property based in the expectation of increased value.

- Expansion of political corruption. It can obtain great benefits if the local government change permitted uses from rural land to developable urban land.

We can say that the private ownership of land for urban development combined with private management for urban development have been factors that have facilitated personal enrichment by speculative activities against environmental public interest. Often, environmental security instruments have not met their objectives.

\subsection{Top consumption phase}

The Capital Consumption Phase ends when it reaches a maximum beyond which prices cannot grow because there is no ready market to buy. So the housing is no longer a good investment and the speculative process stops. 2006 saw the first signs of exhaustion of the cycle.

Worldwide, the cycle stopped when the international banking realised that some international real estate funds were doubtful. It created distrust between 
banks, and the interbank market stopped. Spanish banks cannot sell more mortgage funds in international market. From this moment the Spanish banks set strict conditions for granting mortgage loans. These circumstance occurred in 2007. However, real estate activity to continue to complete houses has begun. This is a normal connection between real estate cycles and economic cycles. Normally the real estate cycle end 1 or 2 years after the end of the economic cycle. This has happened in Spain (see Figures 1 and 2).

At the time of cycle changes, the capital consumption is maximal. In Spain the maximum housing construction occurs in 2006 with 911.568 housing starts in Spain. In Valencia 125.877 dwellings were started in that year.

\subsection{Crash of monetary flows phase}

The cycle crashes when the speculative money flows are broken. These flows are broken when the international banking checks that cannot recover the investment in subprime mortgages. Also the amount of capital at risk isn't known. Then the interbank market closed in 2007.

The Spanish bank stopped loans for real estate initiatives, and as an important part of activity of housing and land without a market, the level of monetary liquidity is low, so the banks also fail to lend for other activities. Also, they fail to lend to the public administration, especially the municipalities which have based their budgets on income derived from real estate. So there was a domino effect of business closures.

At this time there is a fall of housing demand. Housing production fell and the unemployment in the sector increased because activity gradually ended. Central government attempts to mitigate the effects by social assistance and promotion of public works. The public debt increased (by increasing costs and declining revenue.) In two years the budget deficit increases sharply. All this combined produces a decrease in cash flow and payments for completed works.

Table 1: Debt Spain, 2010. Origin: Banco de España.

\begin{tabular}{|c|c|c|c|}
\hline & & $\begin{array}{c}\text { Debt } \\
\text { (€ billions) }\end{array}$ & \\
\hline \multirow[t]{2}{*}{ Public Administrations } & Central Administration & 450 & \\
\hline & $\begin{array}{l}\text { Regional Government } \\
\text { and Local Government }\end{array}$ & 150 & \\
\hline \multirow{2}{*}{ Families } & Mortgage & 680 & \\
\hline & Other & 220 & \\
\hline \multirow[t]{2}{*}{ Enterprises } & IBEX group & 590 & \\
\hline & Other & 720 & Debt per capita \\
\hline TOTAL & & 2.810 & $62444 € /$ inh \\
\hline EXTERN DEBT & & 1.780 & $39500 € /$ inh \\
\hline
\end{tabular}


From the social point of view, it is generally considered that boom situation will return. After 8 years of real estate expansion, people think generally that's the normal situation and the crisis will be a temporary situation. So stakeholders expect a new housing boom and they are prepared for it. There is a state of expectation and no decisions are made for a change of economic model.

At the end of 2010 it is estimated that in Spain there are still between 800,000 and 1.5 million new houses for sale. In addition there are large tracts of developed land but without buildings, especially on the coast. The transformation of land and the landscape is irreversible.

In 2010 the EU requires Spain to control and reduce the deficit. Simultaneously, the private sector gradually stabilizes but does not generate employment.

In 2010 the Spanish savings banks has $€ 23$ billion of foreclosed real estate in land and $€ 21$ billion of completed housing and houses under construction [8]. The savings banks (and also others banks) have a risky asset in land for urban development.

There has been no reinvestment of capital accumulated. There has been no accumulation of capital by the bank. Social protection systems have avoided extreme degradation of the living conditions of people, especially the unemployed population.

\subsection{New equilibrium phase}

In the Spanish case it can be said that the adjustment period of private economic activity took place between 2007 and 2010. Probably the adjustment of public administration will be produced during the years 2011 and 2012. Thus in approximately 2013 we will reach a new equilibrium with a lower GDP.

It is not known how long it will take to normalize the housing market. According to various studies, the housing market will stabilize after 2015 with a production of about 200,000 houses per year.

Most of the people remain in the expectation of returning to another real estate cycle expansion of easy money. Except for some minorities, people do not assume the need to produce goods and services without mortgaging in the future. Most people prefer immediate spending and political representative's act accordingly.

\subsection{Capital increase phase}

After, if people want to increase the money flow, it should increase its capital (stock or reserves). That is, it should promote long-term economic activity and efficient spending of resources (for example landscape) and proper management of emissions.

\section{Conclusion}

We can distinguish six stages in the process of unsustainable development. At first the consumption of capital (stocks or resources) allowed strong economic 
growth (high GDP growth). The population welcomes this process . When it runs out of capital consumption, there is a crisis and a failure of monetary flows.

Most of the people expected to develop new situations of economic expansion. Only a minority perceive the continued degradation of resources which inevitably will mean less progress for the future.

The new equilibrium state corresponds to a lower GDP. To increase again the GDP it is necessary to gradually increase the capital (stocks or reserves).

The private ownership of land for urban development has facilitated the speculative land processes and, finally, the general environmental and economic regression.

\section{References}

[1] Miralles i Garcia, J.L. Sustainability regulations in urban planning: the experience of the Autonomous Community of Valencia (Spain). Proc of the $4^{\text {th }}$ Int. Conf. on Sustainable Development and Planning, eds. C.A. Brebbia, M. Neophytou, E. Beriatos, I. Ioannou \& A.G. Kungolos, WIT Press: Southampton, pp. 3-12, 2009.

[2] Fernandez Ordóñez, Miguel. The restructuring of the Spanish banking sector and the Royal Decree-Law for the reinforcement of the financial system, http://www.bde.es/webbde/es/

[3] Miralles i Garcia, J.L., 2009, op.cit.

[4] Naredo, J.M. La burbuja inmobiliario-financiera en la coyuntura económica reciente (1985-1995). Siglo XXI de España Editores, S.A. Madrid, 1996.

[5] Pilehvar, A.A. \& Kamali, N. The government and urban structure unsustainability in Iran. Proc of Sixth International Conference on Urban Regeneration and Sustainability, The Sustainable City VI, eds. C.A. Brebbia, S. Hernández and E. Tiezzi. WIT Press: Southampton, pp 41-52, 2010 .

[6] Miralles i Garcia, J.L. The introduction of the sustainability in the procedures regulated for urban planning: the case of the last act on urbanism, territory and landscape in the Valencian Community (Spain). Proc of the $3^{\text {rd }}$ Int. Conf. on Sustainable Development and Planning, eds. A. Kungolos, C.A. Brebbia \& E. Beriatos, WIT Press: Southampton, pp. 505-513, 2007.

[7] Gómez F., Montero L., De Vicente V., Sequí A. \& Langa J. Expansion of metropolitan areas, land use and sustainability indicators: the case of Valencia (Spain). Proc of Sixth International Conference on Urban Regeneration and Sustainability, The Sustainable City VI, eds. C.A. Brebbia, S. Hernández and E. Tiezzi. WIT Press: Southampton, pp 3-15, 2010.

[8] Fernández Ordoñez, Miguel, op. cit. 